\title{
Influence of ultrasound and irrigant solutions on the bond strength of glass fiber posts to root canal dentine
}

Influência do ultrassom e de soluções irrigantes na resistência de união de pinos de fibra de vidro à dentina do canal radicular

Ana Júlia Farias LACERDA ${ }^{1}$, Marina Augusto GULLO ${ }^{1}$, Ana Claudia Carvalho XAVIER ${ }^{1}$, César Rogério PUCCI ${ }^{1}$, Cláudio Antonio Talge CARVALHO $^{1}$, Maria Filomena Rocha Lima HUHTALA ${ }^{1}$

1 - Institute of Science and Technology, UNESP - Univ Estadual Paulista, São José dos Campos (SP), School of Dentistry, Department of Restorative Dentistry - São José dos Campos - SP - Brazil

\section{ABSTRACT}

Objective: Assessment of the influence of the ultrasound and irrigant solutions on the bond strength (BS) of glass fiber posts. Material and Methods: Sixty-six roots of bovine teeth standardized at $16 \mathrm{~mm}$ were used. The roots were submitted to a biomechanical preparation up to size \#80 Kerr file, with irrigation of $5 \mathrm{ml}$ of saline solution at every file change and then filled. The canals underwent partial desobturation and were divided into 6 groups according to the irrigant solution and the use of ultrasound prior to the post cementation: $\mathrm{S}-$ saline solution; $\mathrm{C}-2 \%$ chlorhexidine solution; $\mathrm{H}-2.5 \%$ sodium hypochlorite solution; US - saline solution + ultrasound; UC $-2 \%$ chlorhexidine solution + ultrasound; $\mathrm{UH}-2.5 \%$ sodium hypochlorite solution + ultrasound. After the cementation of the posts, the specimens were cut into 3 slices of $2 \mathrm{~mm}$ of thickness, perpendicular to its long axis. The samples were submitted to push-out test with crosshead speed of $1 \mathrm{~mm} / \mathrm{min}$ and load of 50kgf. The data obtained were submitted to ANOVA and Tukey test (level of significance of $5 \%)$. Results: Groups C $7.77( \pm 1.8)^{\mathrm{a}}$, UC $7.82( \pm 1.6)^{\mathrm{a}}$, S $7.33( \pm 2.2)^{\mathrm{a}}$, US $6.16( \pm 2.3)^{\mathrm{a}}, \mathrm{H}$ $5.43( \pm 1.3)^{\mathrm{b}}$, UH $5.01( \pm 2.3)^{\mathrm{b}}$ values in Mpa. Only the irrigant solutions showed statistically significant differences $(<0.05)$. Tukey test revealed smaller bond strength for the specimens treated with Sodium Hypochlorite (b). Conclusions: The ultrasound treatment did not show significant difference compared with the other groups; therefore, its use can be indicated prior to the cementation of glass fiber posts without damage to the bond strength. The sodium hypochlorite solution showed the smallest BS values compared with the other groups.

\section{KEYWORDS}

Adhesiveness; Glass fiber posts; Chlorhexidine; Sodium hypochlorite; Ultrasound.

\section{RESUMO}

Objetivo: Avaliação da influência do ultrassom e de soluções irrigadoras sobre a resistência de união (RU) de pinos de fibra de vidro. Material e Métodos: Utilizou-se 66 raízes de dentes bovinos, padronizadas em $16 \mathrm{~mm}$. As raízes foram submetidas a preparo biomecânico até Lima Kerr \#80, com irrigação de 5 $\mathrm{ml}$ de solução salina fisiológica a cada troca de lima, e foi realizada a obturação. Os espécimes foram parcialmente desobturados e divididos em 6 grupos de acordo com a solução irrigadora e a utilização de ultrassom antes da cimentação do pino: $\mathrm{S}$ - solução salina; C - solução de clorexidina $2 \% ; \mathrm{H}$ - solução de hipoclorito de sódio 2,5\%; US - solução salina + ultrassom; UC - solução de clorexidina $2 \%+$ ultrassom; UH - solução de hipoclorito de sódio 2,5\% + ultrassom. Após a cimentação dos pinos, os espécimes foram seccionados em 3 fatias de $2 \mathrm{~mm}$ de espessura, perpendiculares ao seu longo eixo. Os corpos de prova foram submetidos ao teste de push-out com velocidade $1 \mathrm{~mm} / \mathrm{min}$ e carga de $50 \mathrm{kgf}$. Os dados obtidos foram submetidos aos testes de ANOVA e Tukey (nível de significância 5\%). Resultados: Grupos C 7,77( $\pm 1,8)^{\mathrm{a}}$, UC $7,82( \pm 1,6)^{\mathrm{a}}, \mathrm{S} 7,33( \pm 2,2)^{\mathrm{a}}$, US 6,16( $( \pm 2,3)^{\mathrm{a}}, \mathrm{H} 5,43( \pm 1,3)^{\mathrm{b}}$, UH 5,01( $\pm 2,3)^{\mathrm{b}}$ valores em Mpa. Apenas as soluções irrigadoras apresentaram diferença estatística relevante $(<0,05)$. Ao teste de Tukey, percebeu-se uma resistência menor aos espécimes tratados com Hipoclorito de Sódio (b). Conclusões: O tratamento com ultrassom não demonstrou diferença significante em relação aos demais grupos, portanto pode ser indicado antes da cimentação de pinos de fibra de vidro sem prejuízo na resistência de união. A solução de hipoclorito de sódio apresentou os menores valores de RU comparados aos demais grupos.

\section{PALAVRAS-CHAVE}

Adesividade; Pino de fibra de vidro; Clorexidina; Hipoclorito de sódio; Ultrassom. 


\section{INTRODUCTION}

7 he restorative treatments considerably 1 progressed with the possibility of the adhesiveness of the dental materials to the mineralized tooth tissues. Because the glass fiber posts exhibit a modulus of elasticity close to that of dentine, they provide a restorative treatment with less possibility of failures such as root fracture [1]. Notwithstanding, there are controversial issues regarding to the efficiency of the adhesiveness of the resin cements and their respective adhesive systems to root dentine.

One of the problems of the adhesive systems is the lack of action of the light coming from the light-curing units within the root canals. To solve this aforementioned issue, either dual or self-curing cements have been used aiming to assure the complete polymerization of the cement [2].

With the development of adhesive materials, it is increasingly clearer that the removal or modification of the smear layer is essential to form a proper hybrid layer [4-7].

The employment of 37\% phosphoric acid onto dentine is currently the method that is most mastered in terms of adhesiveness. However, alternative treatment methods such as laser and ultrasound application have been discussed in literature [8].

It has been verified through scanning electronic microscopy that the root canal cleaning performed with ultrasound instrumentation is more effective than hand instrumentation in eliminating the smear layer [9-10]

Additionally to the type of treatment applied, the intraradicular dentine is also influenced by factors such as: the action of the instrumentation during the root canal preparation; the action of the endodontic irrigant solutions on the mineral and organic composition; permanence of these substances within the root canal structure [3].

Sodium hypochlorite $(\mathrm{NaOCl})$ is one of the irrigant solutions largely employed presenting properties as broad antimicrobial spectrum and the capacity of solving organic matter and necrotic tissue [11-12]. On the other hand, $2 \%$ chlorhexidine gluconate has emerged as an alternative irrigant solution for $\mathrm{NaOCl}$ because it is biocompatible [13], it has broad spectrum [14]. and substantivity [15].
Therefore, to assess the influence generated by endodontic irrigant solutions and ultrasound instrumentation on the adhesion of glass fiber posts cemented with resin cement, the aim of this study was to measure the extrusioncompression resistance of colorless glass fiber posts cemented into root canals of bovine teeth through push-out test. This test provides a better estimative of the bond strength of the post to the root dentine because the loading applied parallely to the adhesive interface predominantly results in shear stresses [16].

\section{MATERIAL AND METHODS}

Sixty-six bovine teeth were used and had their crowns removed with the aid of a diamond disc (90 $\mu \mathrm{m}$ - Microdont Micro Usinagem de Precisão Ltd, São Paulo, SP, Brazil) at low speed. The roots had their length standardized at $16 \pm 1$ $\mathrm{mm}$.

The roots were submitted to the endodontic treatment comprising biomechanical preparation through classic hand technique with Kerr files (Dentsply/Maillefer, Ballaigues, Switzerland) and working length at $1 \mathrm{~mm}$ short of the apex. For standardization, apical stop was established at size \#80 Kerr file. At every file change, the specimens were irrigated with $5 \mathrm{ml}$ of saline solution. After biomechanical preparation, the root canals were filled through lateral condensation technique with guttapercha points (Dentsply Ind. E Com. Ltda, Catanduva, SP, Brazil) and calcium hydroxidebased sealer (Sealer 26, Dentsply De Trey, Konstanz, Germany). The specimens were kept in an incubator at $37{ }^{\circ} \mathrm{C}$ and relative humidity for 7 days, to reach the total curing of the endodontic sealer.

The specimens were fixed in colorless acrylic resin (Jet, Artigos Odontológicos Clássico, São Paulo, SP, Brazil) at $3 \mathrm{~mm}$ short of the apex. During this procedure, the teeth were maintained perpendicular to the ground with the aid of delineator. After, the specimens underwent partial desobturation leaving $3 \pm 1$ $\mathrm{mm}$ of filling material in the root apex. For this purpose, the burs of the system of glass fiber post (White Post DC3 and DC4, FGM Produtos Odontológicos, Joinville, SC, Brazil), compatible with the size of the root canal were used. 
The specimens were divided into 6 groups $(n=11)$, according to the irrigant solution and use of ultrasound prior to the cementation of glass fiber posts: $\mathrm{S}-$ saline solution; $\mathrm{C}-2 \%$ chlorhexidine solution; $\mathrm{H}-2.5 \%$ sodium hypochlorite solution; US - saline solution + ultrasound; UC $-2 \%$ chlorhexidine solution + ultrasound; $\mathrm{UH}-2.5 \%$ sodium hypochlorite solution + ultrasound.

The canals were then irrigated with $5 \mathrm{ml}$ of the irrigant solution assigned to each group and the ultrasound was applied into the groups US, UC and UH. The ultrasound device used was CVDent 1000 (Clorovale Diamantes Indústria e Comércio S/A, São José dos Campos, SP, Brazil) with TOS-E2 tips passed onto the root canal wall for $15 \mathrm{~s}$, totalizing 10 rounds with power at $10 \%$.

The root canals were dried with the aid of paper points and air jet to avoid remnants of the material employed previously. Following, the selfetching dual-cure adhesive system (Futurabond $D C$, VOCO GmbH, Cuxhaven, Germany) was applied with the aid of a microbrush, brushing it onto the root canal walls for $20 \mathrm{~s}$. The solvent was dispersed with air jet for $5 \mathrm{~s}$. According to the manufacturer's instructions the adhesive layer was not light-cured.

An epoxy-based resin of dual cure (Bifix $Q M$, VOCO GmbH, Cuxhaven, Germany) was applied, with the aid of the mixer tip of the double syringe. The cement was injected within the root canal, starting from the apical extremity towards the pulp chamber. Following, the glass fiber post was embedded with cement and placed into the root canal to assure that there was a slight excess. The post was kept into position through applying firm pressure for 5-10 s, followed by its light-curing for $40 \mathrm{~s}$ with the light guide placed towards the post direction. The specimens were kept in and incubator at $37^{\circ} \mathrm{C}$ and relative humidity for 7 days.

Then, the specimens were fixed to the metallic base of the cutting machine (LabCut 1010, EXTEC-ERIOS, São Paulo, SP, Brazil) and perpendicularly sectioned at the long axis of the root with the aid of a diamond disc (WFR BLDE 4" X 0.12" X 1/2" - EXTEC-ERIOS, São Paulo, SP, Brazil) under copiously water cooling. The first cervical cut of about $1 \mathrm{~mm}$ thick was discarded because it could exhibit imperfection in the adhesive zone due to mainly the presence of the oxygen. For each specimen, three slices of about $2 \mathrm{~mm}$ thick were obtained. At each cut, the slices were marked for the correct positioning in the push-out test. Prior to the test, the diameter of the post/cements set and the height of the sample were measured with the aid of a digital caliper (Starret ${ }^{\circledR}$ 727, Starret, Itu, SP, Brazil).

The push-out test was performed in an universal testing machine (EMIC model DI-1000 - EMIC, Curitiba, PR, Brazil) at crosshead speed of $1 \mathrm{~mm} \cdot \mathrm{min}^{-1}$ and load cell of $50 \mathrm{Kgf}$.

During the mechanical test, each specimen was placed onto a metallic device with a central opening greater than the root canal diameter, so that the load was applied towards cervical direction up to the displacement of the post/ cement set. With the aid of a cylindrical device with diameter compatible with the diameter of the post + cement set, the load was applied onto the post, without the device touching the dentine.

With the use of the measurements previously obtained, the bond strength (ó) was obtained through the following formula: ó $=\mathrm{C} / \mathrm{A}$, where $\mathrm{C}=$ load for displacing the sample (kgf) and $\mathrm{A}=$ interfacial area $\left(\mathrm{mm}^{2}\right)$. Then, $\mathrm{A}=\pi$.g. $\left(\mathrm{R}_{1}+\mathrm{R}_{2}\right)$, where, $\mathrm{A}=$ interfacial area, $\pi=3.14, \mathrm{~g}$ $=$ generator of the trunk, $R_{1}=$ radius of the short base, $R_{2}=$ radius of the large base, $h=$ height of the section. For the calculus of the generator of the trunk will be used $g^{2}=h+\left[R_{2} R_{1}\right]^{2}$.

The result of the bond strength ó, initially in $\mathrm{kgf} / \mathrm{mm}^{2}$, was transformed into $\mathrm{MPa}$, by multiplying the ó value by 10 , considering the following matching of the measurements: $1 \mathrm{kgf} /$ $\mathrm{mm}^{2}=10 \mathrm{~N} / \mathrm{mm}^{2}=10 \mathrm{MPa}$.

The original data obtained were submitted to two-way ANOVA (irrigant solution and ultrasound use) and Tukey test, with level of significance of $5 \%$.

\section{RESULTS}

The mean and standard deviation of the push-out test, showing the bond strength values for each group are seen in Table 1. 
Table 1 - Bond strength in MPA (mean and standard deviation) of the different groups varying the irrigant solution and dentine treatment $(n=11)$

\begin{tabular}{|ccc|}
\hline \multirow{2}{*}{ Irrigant solutions } & \multicolumn{2}{c|}{ Dentine Treatment } \\
& Without ultrasound & With ultrasound \\
\hline Saline & $7.33 \pm 2.29$ & $6.16 \pm 2.32$ \\
\hline Chlorhexidine & $7.77 \pm 1.83$ & $7.82 \pm 1.63$ \\
\hline Sodium Hypochlorite & $5.43 \pm 1.39$ & $5.01 \pm 2.13$ \\
\hline
\end{tabular}

The statistical results of ANOVA test (level of significance of 5\%) demonstrated that there were no statistically significant differences for the use or non-use of ultrasound; there was statistically significant differences regarding the irrigant solution type used during the biomechanical preparation. After the application of Tukey test (Table 2), it was evidenced that the groups using sodium hypochlorite as adjunct chemical substance exhibited the smallest bond strength values (5.22 $\mathrm{MPa}$ ) which were statistically different from those of the groups Saline (6.74 MPa) and Chlorhexidine (7.8 MPa).

Table 2 displays the result of Tukey test for the factor "irrigant solution".

Table 2 - Result of the Tukey Test $(p \ll 0.05)$

\begin{tabular}{|cc|}
\hline Irrigant Solutions & Mean \\
\hline $\mathrm{NaOCl}$ & $5.22 \mathrm{a}^{\star}$ \\
\hline Saline & $6.74 \mathrm{~b}$ \\
\hline Chlorhexidine & $7.8 \mathrm{~b}$ \\
\hline
\end{tabular}

* -Different letters mean significant differences ( $p$ «0.05).

\section{DISCUSSION}

Many methods have been utilized to measure the bond strength to root dentine, such as the shear bond, microtensile and push-out tests [17]. The thin slice employed in the push-out test has been reported to be a useful tool to evaluate the bonding of fiber posts [18]. This method is more advantageous than the shear bond and microtensile test because it presents absence of premature failures, ease of sample construction for the tests, and less susceptibility to small variations among the samples and variations in the stress distribution [19].

A study conducted by Scotti et al. evaluated the influence of the etching procedure on the bond strength of glass fiber posts cemented into root canal. This study concluded the need of the acid etching onto the dentine of the root canal, even when self-etching adhesive agents were used because the groups etched showed higher bond strength values than those of the groups in which only the self-etching adhesive systems had been used [20].

Considering our choice for a self-etching adhesive agent and for avoiding the use of acid etching, we applied an alternative technique for the elimination of the smear layer: the use of ultrasound.

A study conducted by Conde, in 2004, affirmed that the dentine surface treated with ultrasound exhibits a greater contact surface suitable for the use of the adhesive technique [21]. When CVD Diamond tips are used in the ultrasound device, according to Vieira and Vieira, there is either a smaller residual presence of smear layer or its absence, because of the direct action of the CVD diamond which are formed from a single diamond stone with a rough and well-ordered surface and do not undergo an appreciable weariness after its use and/or the phenomenon of water's ultrasonic (refrigeration) which results in energy releasing for the cavity cleaning, acting as an agent for the removal of dentinal debris [22]. Notwithstanding, in this present study there was no statistically significant difference in the bond strength between the dentine treated either conventionally or with ultrasound.

Other important aspect to be considered is the restorative material to be used. In endodontically treated teeth, one should preferably opt to use restorative materials showing mechanic characteristics similar to that of the tooth structure lost, that is, restorative material that biomimics these structures [23]. Most of these materials is the adhesive agent which enables the formation of a continue body between the tooth/restorative material, also providing the distribution of the stresses generated during mastication more homogenously, minimizing the risk of root fracture [24]

Ozcan et al. (2012) evaluated through push-out test, the bond strength of three resin cements (chemically curing, dual curing, and 
light curing). The author concluded that the dualcuring cement displayed the best bond strength values. Consequently, in this present study, we opted to use a dual-curing adhesive system [25]

The chemical irrigant substances utilized during the endodontic treatment may also influence on the bond strength of the resin cement to root dentine because they can be dissociated into oxygen and water and diffused within the collagenic matrix and dentinal tubules, affecting either the penetration of the resin materials into the dentine structure or the polymerization of the monomers [24]. and consequently increasing the risk of fracture of these roots. Other factor that may also negatively interfere in the bonding process is the degradation of the collagenic fibrils from the dentinal surface caused by the use of these irrigant substances, which hinder the formation of a solid hybrid layer [26].

According to Morris et al., 2001; Ari et al., 2003 and Erdemir et al. 2004, the degradation provoked by sodium hypochlorite influence on the degradation of the values of bond strength to root dentine, mainly when at high concentrations because the action of oxidation of sodium hypochlorite leads to the oxidation of the collagenic fibers of the dentine which is critical for the starting of the polymerization [27-28-29]. Erdemir et al. (2004), verified that the root canal irrigation with $0.2 \%$ chlorhexidine gluconate increases the values of bond strength to root dentine. The authors attribute this result to the adsorption characteristic of chlorhexidine, that is, its molecules exhibit positive ionic charge capable of linking to other substrates negatively charged, such as tooth tissues and the adhesive molecule itself, strengthening the tooth/resin bonding [29]. On the other hand, Santos concluded that the bond strength to dentine was not affected by endodontic irrigation with $2.0 \%$ chlorhexidine gluconate, both liquid and gel, displaying mean values of bond strength similar to those of the control group [30], result equal to that of this study which concluded that the dentine treatment with sodium hypochlorite showed bond strength values statistically smaller than that of teeth treated with chlorhexidine gluconate and saline.

\section{CONCLUSION}

Based on the results of this study, it can be concluded that:

- The treatment of root dentine with ultrasound previously to the cementation of pre-fabricated posts with resin cements did not cause any alteration sensible to BS.

- Among the irrigant solutions used, sodium hypochlorite exhibited the smallest bond strength values.

\section{REFERENCES}

1. White RR, Goldman M, Lin PS. The influence of the smeared layer upon dentinal tubule penetration by plastic filling materials. J. Endod. Dec 1984; 10(12),558-62.

2. Paul, S. J. Adhesive luting procedures. Berlin: Quintessenz; 1997.

3. Pashley DH. Smear layer: physiological considerations. Oper Dent Suppl. 1984;3:13-29.

4. Van Meerbeek B, De Munck J, Yoshida Y, Inoue S, Vargas M, Vijay $P$ et al. Adhesion to enamel and dentin: curret status and future challenges. Oper Dent. 2003;28:215-35.

5. Ermis RB, De Munck J, Cardoso MV, Coutinho E, Van Landuyt $\mathrm{KL}$, Poitevin $A$ et al. Bond strength of self-etch adhesives to dentin prepared with three different diamond burs. Dent Mater. 2008;24:978-85.

6. Oda M, Oliveira DC, Liberti EA. Avaliação morfológica da união entre adesivo/resina composta e dentina irradiada com laser Er:YAG e laser Nd:YAG: estudo comparativo por microscopia de varredura. Pesqui Odontol Bras. 2001;15(4):283-9.

7. Wuchenid G, Meadonws D, Torabinejad M. A comparison between two root end preparation techniques in human cadavers. J Endod. 1994 Jun;20(6):279-82.

8. Bowen RL, Eick JD, Henderson DA, Anderson DW. Smearlayer: removal and bonding considerations. Oper Dent Suppl. 1984;3:30-4.

9. Ari H, Erdemir A, Belli S. Evaluationof the effectof endodontic irrigation solutions on the microhardness and the roughnessof rootcanal dentin. J Endod. 2004 Nov;30(11):792-5.

10. Okşan T, Aktener BO, Sen BH, Tezel H. The penetration of root canal sealers into dentinal tubules. A scannig electron microscopy study. Int Endod J.1993;26(5):301-5.

11. Zehnder M. Root canal irrigants. J Endod. 2006;32(5):389-98. 
12. Carson KR, Goodell GG, McClanahan SB. Comparison of the antimicrobial activity of six irrigants on primary endodontic pathogens. J Endod. 2005;31(6):471-3.

13. Semenoff TA, Semenoff Segundo A, de Figueiredo JA. Biocompatibility of different intracanal medications in rat bucal submucosa tissue. J Appl Oral Sci. 2008;16(1):12-7.

14. Kayaoglu G, Omurlu H, Akca G, Gurel M, Gencay 0, Sorkun K, et al. Antibacterial activity of Propolis versus conventional endodontic disinfectants against Enterococcus faecalis in infected dentinal tubules. J Endod. 2011;37(3):376-81.

15. Shahani MN, Subba Reddy VV. Comparison of antimicrobial substantivity of root canal irrigants in instrumented root canals up to $72 \mathrm{~h}$ : an in vitro study.

J Indian Soc Pedod Prev Dent. 2011;29(1):28-33.

16. Kurtz JS, Perdigao J, Geraldeli S, Hodges JS, Bowles WR. Bond strengths of tooth-colored posts, effect of sealer, dentin adhesive, and root region. Am J Dent. 2003;16(Spec n):31A-36A.

17. Goracci C, Grandini S, Bossu M, Bertelli E, Ferrari M. Laboratory assessment of the retentive potential of adhesive posts: a review. J Dent 2007;35:827-35.

18. Goracci C, Tavares AU, Fabianelli A, Monticelli F, Raffaelli 0, Cardoso PC. The adhesion between fiber posts and root canal walls: comparison between microtensile and push-out bond strength measurements. Eur J Oral Sci 2004;112(4):353-61.

19. Ungor M, Onay EO, Orucoglu H. Push-out bond strengths: the Epiphany-Resilon endodontic obturation system com- pared with different pairings of Epiphany, Resilon, AH Plus and gutta-percha. Int Endod J. 2006;39(8):643-7.

20. Scotti N, Rota R, Scansetti M, Migliaretti G, Pasqualini D, Berutti E. Fiberpost adhesion to radicular dentin: The use of acid etching prior to a one-step self-etching adhesive. Quintessence Int. 2012 Jul-Aug;43(7):615-23.
21. Conde A. Estudo comparativo entre preparo cavitário ultrassônico e alta-rotação. RG0. 2004 Jul/Aug/Sep;52(3):169-72.

22. Vieira $D$, Vieira $D$. Pontas de diamante CVD: início do fim da alta rotação? JADA - Brasil. 2002 Sep./0ct;5(5):307-13.

23. Pest LB, Cavalli G, Bertani P, Gagliani M. Adhesive postendodontic restorations with fiber posts: push-out tests and SEM observations. Dent Mat. 2002 Dec;18(8):596-602.

24. Nikaido T, Takano Y, Sasafuchi Y, Burrow MF, Tagami J. Bond strengths to endodontically-treated teeth. Am J Dent. 1999 Aug;12(4):177-80.

25. Ozcan E, Cetin AR, Tunçdemir AR, Ulker M. The effect of luting cement thicknesses on the push-out bond strength of the fiber posts. Acta Odontol Scand. 2013 May-Jul;71(3-4):703-9.

26. Ozturk B, Ozer F. Effect of $\mathrm{NaOCl}$ on bond strengths of bonding agents to pulp chamber lateral walls. J Endod. 2004 May;30(5):362-5.

27. Morris MD, Lee KW, Agee KA, Bouillaguet S, Pashley DH. Effects of sodium hypochlorite and RC-prep on bond strengths of resin cement to endodontic surfaces. J Endod. 2001 Dec;27(12):753-7.

28. Ari $\mathrm{H}$, Yasar E, Belli S. Effects of $\mathrm{NaOCl}$ on bond strengths of resin cements to root canal dentin. J Endod. 2003 Apr;29(4):248-51.

29. Erdemir A, Ari H, Gungunes H, Belli S. Effect of medications for root canal treatment on bonding to root canal dentin. J Endod. 2004 Fev;30(2):113-16.

30. Santos JN, Carrilho MR, Goes MF, Zaia AA, Gomes BPA, Souza-Filho FJ, et al. Effect of chemical irrigants on the bond strengths of a self-etching adhesive to pulp chamber dentin. J Endod. 2006 Nov;32(11):1088-90.

\section{Ana Júlia Farias Lacerda \\ (Corresponding author)}

Instituto de Ciência e tecnologia

Depto de Dentística Restauradora

Av. Eng. Francisco José Longo, no 777

Bairro: Jardim São Dimas

Received: 2013 Feb 01

12245-000 - São José dos Campos, SP 